\title{
Milk urea concentration as an indicator of ammonia emission from dairy cow barn under restricted grazing
}

\author{
G. van Duinkerken, ${ }^{\star 1}$ M. C. J. Smits, ${ }^{\star}$ G. André, ${ }^{*}$ L. B. J. Šebek, ${ }^{\star}$ and J. Dijkstra† \\ *Wageningen UR Livestock Research, PO Box 65, 8200 AB, Lelystad, the Netherlands \\ †Animal Nutrition Group, Wageningen University, PO Box 338, $6700 \mathrm{AH}$, Wageningen, the Netherlands
}

\begin{abstract}
Bulk milk urea concentration was evaluated to assess its potential as an indicator of ammonia emission from a dairy cow barn in a situation with restricted grazing. An experiment was carried out with a herd of, on average, 52 Holstein-Friesian dairy cows. The cows were housed in a naturally ventilated barn with cubicles and a slatted floor, were fed ensiled forages and feed supplements, and each day were allowed $8.5 \mathrm{~h}$ of grazing. The experiment was a balanced randomized block design, replicated 3 times. The experimental factor was the bulk milk urea level, which was adjusted to levels of 15 , 35 , and $55 \mathrm{mg}$ of urea per $100 \mathrm{~g}$ of milk, respectively, by changing the level of nitrogen fertilization of the pasture, the herbage mass and grass regrowth age, and the level and type of feed supplement. Ammonia emission from the barn was measured using sulfur hexafluoride as the tracer gas. Ammonia emission generally increased upon an increase in adjusted milk urea levels. A dynamic regression model was used to predict ammonia emission from bulk milk urea concentration, temperature, and a slurry mixing index. This model accounted for $66 \%$ of the total variance in ammonia emission and showed that emission increases exponentially with increasing milk urea concentration. At levels of 20 and $30 \mathrm{mg}$ of urea per $100 \mathrm{~g}$ of milk, ammonia emission increased by about 2.5 and $3.5 \%$, respectively, when milk urea concentration increased by $1 \mathrm{mg} / 100 \mathrm{~g}$. Furthermore, emissions from the barn increased $2.6 \%$ when temperature increased by $1^{\circ} \mathrm{C}$. The study showed that bulk milk urea concentration is a useful indicator for ammonia emissions from a dairy cow barn in a situation with restricted grazing.
\end{abstract}

Key words: ammonia emission, milk urea, restricted grazing

Received March 31, 2009.

Accepted September 7, 2010.

${ }^{1}$ Corresponding author: gert.vanduinkerken@wur.nl

\section{INTRODUCTION}

In the National Emission Ceilings Directive of the European Union (European Union, 2001), maximum emission levels for 2010 are set for the individual countries of the European Union. These maxima concern sulfur dioxide, nitrogen oxides, nonmethane volatile organic components, and ammonia $\left(\mathrm{NH}_{3}\right)$. The Dutch maximum $\mathrm{NH}_{3}$ emission level is $128 \mathrm{kt} / \mathrm{yr}$, with a maximum contribution from the agricultural sector of $96 \mathrm{kt} /$ yr. This target has only a $50 \%$ chance of being achieved with unchanged policy, and additional efforts in the livestock production sector are necessary (VROM, 2007).

Emissions of $\mathrm{NH}_{3}$ from livestock originate largely from urea excreted with urine (Bussink and Oenema, 1998). Urea hydrolysis is catalyzed by the enzyme urease, which is produced by microorganisms that are abundantly present in feces and thus also upon fouled floors and in slurry pits. Urinary urea concentration and temperature are the main factors influencing the rate of $\mathrm{NH}_{3}$ volatilization (Monteny, 2000). Previous experiments and modeling approaches have shown that the urinary urea concentration and urea-nitrogen excretion in grams per day are important predictors of $\mathrm{NH}_{3}$ emission from manure (James et al., 1999) or dairy barns (Smits et al., 1995; Monteny et al., 1998; Cassel et al., 2005). Smits et al. (1997) stated that nutritional measures related to reduction of $\mathrm{NH}_{3}$ emission should focus on reduction of urinary urea concentration by lowering the $\mathrm{N}$ concentration in the diet rather than by increasing the urine volume.

Frank and Swensson (2002) stated that $\mathrm{NH}_{3}$ release from cow manure was reduced when the protein level in the diet was lowered and that the concentration of MUN was positively correlated with protein level in the diet and $\mathrm{NH}_{3}$ emission. In that study, a ventilated chamber and the analytical technique of Andersson (1994) were used to determine $\mathrm{NH}_{3}$ release from feces and urine.

Several studies did not directly assess the effect of diet on ammonia emission but did demonstrate that reducing dietary $\mathrm{CP}$ content resulted in less total $\mathrm{N}$ 
excretion and less urinary $\mathrm{N}$ excretion (Kebreab et al., 2002; Nousiainen et al., 2004; Misselbrook et al., 2005), with MUN being positively correlated to urinary $\mathrm{N}$ excretion (Kebreab et al., 2002; Nousiainen et al., 2004; Burgos et al., 2007). However, the use of MUN to predict urinary $\mathrm{N}$ excretion has been questioned by others (Kauffman and St-Pierre, 2001; Tas et al., 2006), and the robustness of these relationships is debatable. Some studies indicate that MUN alone is not a good indicator for urinary $\mathrm{N}$ excretion and that additional parameters such as BW (Kauffman and St-Pierre, 2001; Kohn et al., 2002) or diet characteristics (De Campeneere et al., 2006) are important.

Misselbrook et al. (2005) reported some shortcomings of laboratory techniques for $\mathrm{NH}_{3}$ emission measurements, although other studies successfully used laboratory techniques (Lascano et al., 2008) or experimental chambers (Powell et al., 2008b) in estimating the effects of diet on $\mathrm{NH}_{3}$ emission. As most dairy cow barns are naturally ventilated, the relevance of (dietary) measures to reduce nitrogen losses by $\mathrm{NH}_{3}$ emission of the dairy barn should best be evaluated making use of measuring techniques for naturally ventilated barns, such as a concentration ratio method using a tracer gas (Monteny and Erisman, 1998; Mosquera Losada, 2007; Schrade et al., 2007). van Duinkerken et al. (2005) used sulfur hexafluoride $\left(\mathrm{SF}_{6}\right)$ as a tracer gas and demonstrated that $\mathrm{NH}_{3}$ emission from a naturally ventilated dairy barn could be significantly reduced by altering the diet. Furthermore, they showed that bulk milk urea concentration is a useful indicator to monitor and control $\mathrm{NH}_{3}$ emission reduction. The study of van Duinkerken et al. (2005) was performed in a situation where cows were confined to the barn $24 \mathrm{~h}$ per day. A remaining question is whether $\mathrm{NH}_{3}$ emission levels from dairy barn can be monitored, controlled, and reduced by using milk urea concentration as an indicator, when farms apply restricted grazing with cows being outdoors for several hours a day. On most Dutch dairy farms, pasturing is applied during the grazing season and Kroodsma et al. (1993) showed that emission rate decreases exponentially when cows have left the house for grazing. Furthermore, it has been demonstrated that $\mathrm{NH}_{3}$ emission is usually rather high during the grazing season (Kroodsma et al., 1993; Powell et al., 2008a), mainly because $\mathrm{NH}_{3}$ emissions are positively correlated with temperature (Monteny, 2000; van Duinkerken et al., 2005; Sommer et al., 2006). Furthermore, the fresh pasture grass that is ingested during grazing is usually rich in $\mathrm{N}$, enhancing the urinary $\mathrm{N}$ excretion.

The aim of the present study was to evaluate the potential of milk urea concentration as an indicator for $\mathrm{NH}_{3}$ emission reduction from a dairy cow barn in a situation with restricted grazing.

\section{MATERIALS AND METHODS}

\section{Experimental Design}

Design and Treatments. The experiment had a balanced randomized block design and was repeated 3 times. There was replication within herd. In this particular experiment, replicate was not a group of animals but one series ( $=$ block) of 3 subperiods of 3 wk each. The 3 treatments were randomized over 3 subperiods within each series. The randomized block design was followed to eliminate series (= block) effects, which improves the power of the experiment. Randomly creating a series of diets over the whole investigation period has the risk of confounding and is less efficient than the approach followed in the current experiment.

The experimental factor was the bulk milk urea level, which was adjusted to 3 levels of 15,35 , and $55 \mathrm{mg}$ of urea per $100 \mathrm{~g}$ of milk, respectively (treatments U15, U35, and U55), corresponding to levels of 7.2, 16.8, and $26.4 \mathrm{mg}$ of MUN/100 mL, respectively. Each level was maintained for $3 \mathrm{wk}$, with periods randomly distributed over the whole research period. The actual sequence of treatments was U35, U15, U55, U35, U55, U15, U15, U35, and U55. The final period of the 9 treatment periods was shortened to 2 wk because adverse weather and grazing conditions (wet and weak pasture surface) prevented cows from grazing. The total duration of the experiment was therefore 26 wk (April 24 to October 22).

Animals and Housing. The experiment was performed at a research farm in Lelystad, the Netherlands. The cubicle house was naturally ventilated with space boarding in one sidewall and no ventilation openings in the other sidewall. The lying area was arranged in 2 rows of 34 and 31 cubicles, respectively, on either side of a central feeding alley. Slurry was stored beneath the slatted floor and the cubicles. The barn is described in more detail by van Duinkerken et al. (2005).

During the experiment, 52 lactating Holstein Friesian dairy cows were present, on average, in the barn, with the exception of a daily 8.5-h grazing period. No youngstock or dry cows were housed in the barn, except for animals in the last $10 \mathrm{~d}$ before their expected calving date, which were added to the lactating herd.

Strategy to Adjust Milk Urea Levels. The prediction model of Schepers and Meijer (1998) was used to predict the milk urea level based on diet composition and to adjust the diet. In this model, the RDP balance according to the Dutch standard ["Onbestendig Eiwit Balans" (OEB); Tamminga et al., 1994] is the predominant factor influencing milk urea concentration.

An area of 15.6 ha was used for grazing and divided into 13 plots of 1.2 ha each. The daily average grazing 
Table 1. Actual amount of feed supplied in the barn (averaged per cow) per treatment replicate

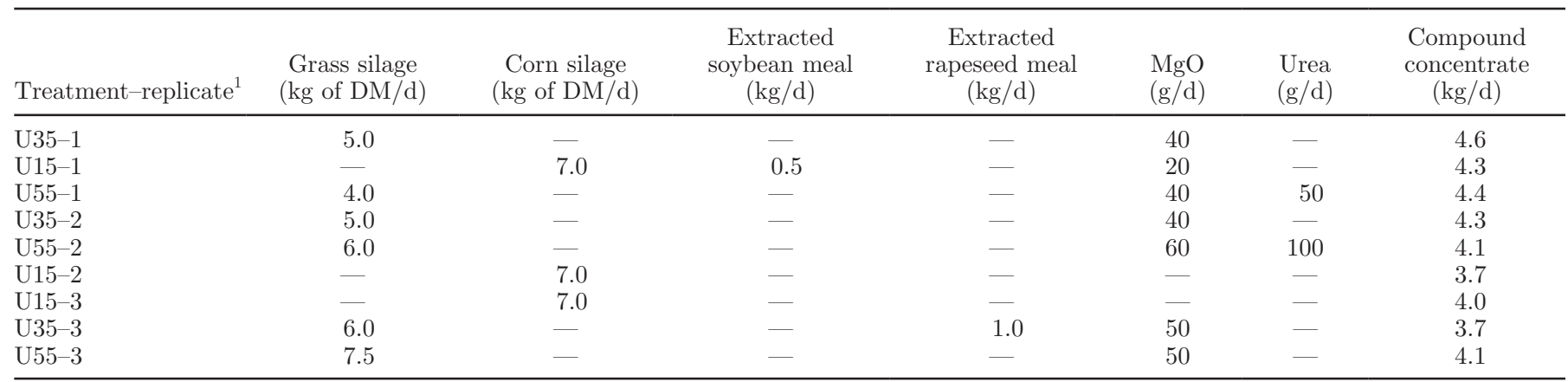

${ }^{1}$ Treatments U15, U35, and U55 included 3 levels of 15, 35, and $55 \mathrm{mg}$ of urea per $100 \mathrm{~g}$ of milk, respectively.

time was $8.5 \mathrm{~h}$ and started around $0730 \mathrm{~h}$. A rotational grazing system was used with an average stay of the herd of 3 sequential days per plot. The sward was a stand of predominantly perennial ryegrass.

A combination of tools was used by a 2-person expert team to control diet composition (thereby influencing milk urea levels) in each treatment period: 1) the level and type of indoor supplemented feed, 2) the level of $\mathrm{N}$ fertilization on individual pasture plots, and 3) the herbage mass and regrowth age of the grass on the pasture plots. Diets were formulated based on the expert team's estimation of feed intake and pasture grass composition, combined with the feed analyses of ensiled forages and concentrates. The composition of diets, but also of compound concentrates, was adjusted for each treatment, taking into account the $\mathrm{NE}_{\mathrm{L}}$ requirements according to the Dutch standard 11 VEM ("Voeder Eenheid Melk") $=6.9 \mathrm{~kJ}$ of $\mathrm{NE}_{\mathrm{L}}$; van Es, 1975, 1978) and true protein digested in the small intestine ["Darmverteerbaar Eiwit" (DVE)] according to the Dutch standard (Tamminga et al., 1994). In the barn, cows were fed (a mixture of) corn and (or) grass silage and occasionally extracted formaldehyde-treated soybean meal or extracted rapeseed meal to increase the level of DVE. In treatment periods U $55-1$ and U55-2 (the first and second periods in which U55 was applied, or periods 3 and 5 chronologically), respectively, 50 and $100 \mathrm{~g}$ of urea/animal per day was added to the forage mixture to increase the OEB of the diet. The forages and supplements were mixed using a feed mixer wagon and were fed at levels shown in Table 1. Finally, compound concentrate was fed according the $\mathrm{NE}_{\mathrm{L}}$ requirement (CVB, 2002) for each individual cow, using 2 computer-controlled concentrate dispensers and including the allocation of $0.5 \mathrm{~kg}$ of compound concentrate in the milking parlor at every milking for each cow.

Fertilizer was adjusted per individual plot according to recommendations for fertilization of grassland and fodder crops of the Dutch Commission on Fertilization of Grassland and Fodder crops (CBGV, 1998) and tak- ing into account the objectives for milk urea levels per treatment. Every week, an expert team visited all plots to judge grass quality and grazing conditions, to set up the grazing strategy for the next week, and to decide on the harvesting and fertilization moments of certain plots to obtain suitable pasture plots for the upcoming weeks.

\section{Measurements and Data}

Feed Intake and Feed Sampling. Intake of pasture grass was not measured. Grass composition and feeding value were analyzed for each of the 9 main periods. Of each parcel used for grazing in the main period, a representative sample was taken at turning into pasture by cutting 25 subsamples equidistantly divided over 3 diagonal lines across the parcel (CVB, 2003). Samples were cut at a height of $6 \mathrm{~cm}$ above the surface and pooled for that main period. Grass samples were preserved by drying during $36 \mathrm{~h}$ at $70^{\circ} \mathrm{C}$ in a forced air oven. Next, they were stored in a dry and dark storage room at room temperature. At the end of the experiment, all 9 pooled grass samples were analyzed by the ALNN laboratory (Wargea, the Netherlands) for DM, inorganic matter (ash), $\mathrm{CP}(\mathrm{N} \times 6.25)$, crude fiber, sugars, $\mathrm{NO}_{3}, \mathrm{Na}$, and $\mathrm{K}$ (all according to CVB, 2003) and in vitro digestibility of organic matter (dOM) according to Tilley and Terry (1963).

In the barn, individual intake of the basal feed mixture was registered with a Hokofarm RIC system (Insentec, Marknesse, the Netherlands), consisting of 40 computer-controlled weighing troughs. Supplemental compound concentrate was fed with 2 automated concentrate dispensers, registering individual concentrate intake per day. Details of sampling of diet, storage of samples, and chemical analyses are given by van Duinkerken et al. (2005).

The actual amounts of feed supplied in the barn are given in Table 1 and feed refusals were negligible. The composition of pasture grass, feed mixture components, 
Table 2. Composition and feeding value [digestibility of OM (dOM) in \% of OM, VEM per $\mathrm{kg}$ of DM, others in $\mathrm{g} / \mathrm{kg}$ of DM] of pasture grass

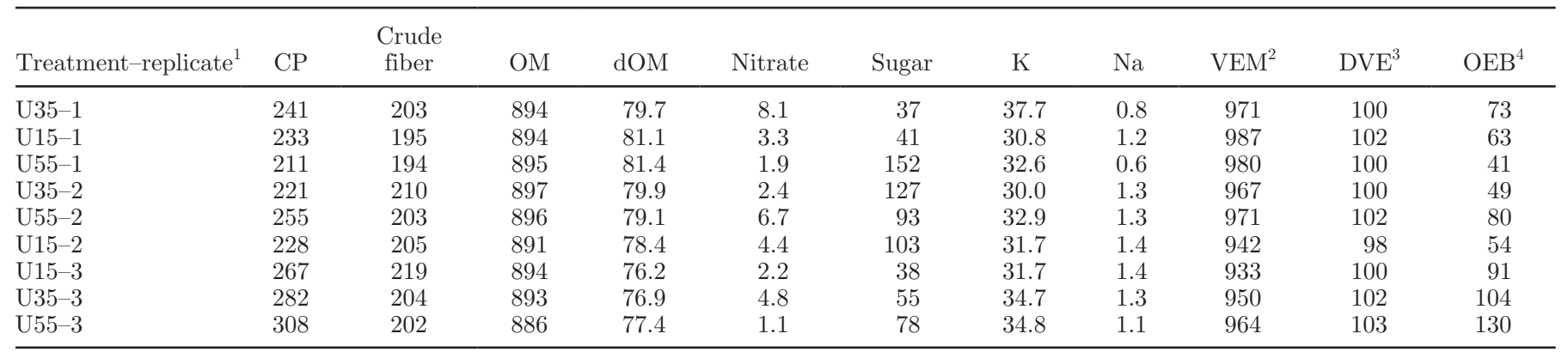

${ }^{1}$ Treatments U15, U35, and U55 included 3 levels of 15, 35, and $55 \mathrm{mg}$ of urea per $100 \mathrm{~g}$ of milk, respectively.

${ }^{2} \mathrm{VEM}=\mathrm{NE}_{\mathrm{L}}$ according to Dutch standards.

${ }^{3} \mathrm{DVE}=$ true protein digested in the small intestine according to Dutch standards.

${ }^{4} \mathrm{OEB}=\mathrm{RDP}$ balance according to Dutch standards.

and compound concentrates are presented in Tables 2, 3 , and 4 , respectively.

Milk Yield and Composition, Including Milk Urea. Cows were milked twice daily at approximately 0600 and $1700 \mathrm{~h}$. Individual milk yield was recorded at each milking. Every week, during the Wednesday p.m. and Thursday a.m. milkings, individual milk samples were taken, pooled per cow, and analyzed for fat and protein content by the "Melk Controle Station" milk-testing laboratory (Zutphen, the Netherlands) according to EN ISO/IEC standard 17025 [International Organization for Standardization (ISO), 2000].

A sample of the bulk milk was taken every 6 milkings (i.e., 3 a.m. and 3 p.m. milkings), just before emptying of the tank. Bulk milk samples were analyzed for milk urea concentration with the Bran and Luebbe Traacs 800 auto-analyzer by the milk-testing laboratory (Zutphen, the Netherlands) according to de Jong et al. (1992). In addition, at every milking, a representative milk sample was taken of the mixed milk of all cows in the herd, by using a needle that was implanted in the central milk pipe of the milking parlor toward the bulk milk tank. Through this needle, a proportional amount of milk was drained from the herd milk and collected in a tube. Before the experiment started, we determined that this needle sampling method gave exactly the same milk urea concentration as sampling of the milk from one herd milking gathered in the bulk tank; the method was validated on 3 randomly selected days. Urea concentration of each herd milk sample was analyzed as described previously.

Urine Composition. On d 1, 3, and 5 of the third week of every 3 -wk period, except in period 9 , urine was sampled. On each sampling day, 2 sampling moments occurred (the first was just before the a.m. milking and the second was before the p.m. milking, when cows just entered the barn after grazing). On these occasions, as many cows as possible were randomly sampled for urine on a voluntary basis (no stimulation). On each occasion, at least 12 cows were sampled using a urine collecting device on a long stick, and urine of each cow was stored in a $60-\mathrm{mL}$ tube, labeled, and cooled immediately in a box with frozen cooling elements. Immediately after the last sample was collected, urine samples were placed in a freezer and later transported frozen to the laboratory. In this laboratory, a pooled sample was made per a.m. or p.m. sample and analyzed for total N, urea-N, $\mathrm{NH}_{4}-\mathrm{N}, \mathrm{Na}, \mathrm{K}$, and $\mathrm{pH}$.

Slurry Sampling. On the first day of every treatment period, the slurry level in the pit was reduced to a remaining level of $75 \mathrm{~cm}$ of slurry to eliminate any possible effect of slurry level on $\mathrm{NH}_{3}$ emission. At the end of a 3 -wk treatment period, about $20 \%$ of the slurry volume in the pit originated from the current treatment and about $80 \%$ from previous treatments. The slurry level was reduced by mixing the slurry followed by pumping the surplus to slurry storage on another location at the farm. Mixing and pumping of slurry was restricted to these times only, such that the composition of the top layer of the slurry in the pit was predominantly influenced by the diet and negligibly by the older, underlying slurry. During mixing, all barn doors were opened to maximize the ventilation rate and to minimize the risk of accumulation of toxic gases.

Per treatment period (except in period 9), 2 sample types were collected in the third week of each treatment period: (1) a sample of the top layer of the slurry and (2) a sample of the mixed slurry. For both sample types, slurry was sampled at 10 evenly distributed locations through the slats. For this purpose, a special sampling device (cup shaped; $100 \mathrm{~mL}$ ) was attached to a long stick. The samples were collected in a jar, stored in a cooler, and transported at $4^{\circ} \mathrm{C}$ to the laboratory. Samples of one sampling moment were mixed, and a pooled sample was analyzed for total $\mathrm{N}, \mathrm{NH}_{4}-\mathrm{N}$, and $\mathrm{pH}$. In addition, for mixed slurry, DM, Na, and $\mathrm{K}$ were analyzed. 
Ammonia Emission Measurements. Emission of $\mathrm{NH}_{3}$ was measured continuously $(24 \mathrm{~h} / \mathrm{d})$ with a concentration ratio method using sulfur hexafluoride $\left(\mathrm{SF}_{6}\right)$ as a tracer gas. Approximately $14 \mathrm{~mL}$ of $\mathrm{SF}_{6}$ per min was injected with the aid of a mass flow controller, and $\mathrm{SF}_{6}$ was diluted in air $(5 \mathrm{~L} / \mathrm{min})$. This air amount was controlled with the aid of another mass flow controller. Tracer gas injection points were installed below a comfort plate at the end of the cubicles near the slatted floor, as illustrated in the cross-section in Figure 1, to ensure optimal distribution of the gas near the source of $\mathrm{NH}_{3}$ emission. There were 30 injection points in total and air was equally distributed over these points by orifices installed at each point. The tracer gas injection was continuously performed during $24 \mathrm{~h} / \mathrm{d}$ over the whole research period. The principle of the constant release tracer gas has also been applied by Demmers et al. (2000; 2001) and Marik and Levin (1996). In a study in a forced-ventilated cow building, the method was validated by Scholtens et al. (2004). Methods for measuring airflow rates were reviewed by Phillips et al. (2001).

Air in the top of the building was continuously sampled using a collecting tube. At 3 points in the top of the building, orifices were installed that allowed a fixed airflow of $500 \mathrm{~mL} / \mathrm{min}$ each (total of $1,500 \mathrm{~mL} / \mathrm{min}$ ). The collecting tube was split in 2 parts after a pump. One branch went to a $\mathrm{NH}_{3}$ converter and a nitrogen oxides $\left(\mathbf{N O}_{\mathbf{x}}\right)$ monitor. Collected air was taken to this $\mathrm{NO}_{\mathrm{x}}$ monitor and a new cycle was started every 6 min. Per 6 min, the $\mathrm{NH}_{3}$ concentration was determined (simultaneously, the background air $\mathrm{NH}_{3}$ concentration in the side wall was determined by using a collecting point in the side wall). The other branch went to a gas chromatograph and an air sample was analyzed for $\mathrm{SF}_{6}$ concentration every $12 \mathrm{~min}$. Six minutes later, a background $\mathrm{SF}_{6}$ concentration was measured (also every $12 \mathrm{~min}$ ). The whole setup operated continuously and automatically.

The source strength of $\mathrm{NH}_{3}$, being the $\mathrm{NH}_{3}$ emission, was calculated by using the following equation, assuming perfect mixing of $\mathrm{NH}_{3}$ and $\mathrm{SF}_{6}$ :

$$
\mathrm{MFSF}_{6}: \mathrm{MFNH}_{3}=\mathrm{CTSF}_{6}: \mathrm{CTNH}_{3} \text {, }
$$

where $\mathrm{MFSF}_{6}=$ mass flux of $\mathrm{SF}_{6}$ injected near the floor $(\mathrm{g} / \mathrm{h}) ; \mathrm{MFNH}_{3}=$ mass flux of $\mathrm{NH}_{3}$ (from floor and pit; $\mathrm{g} / \mathrm{h}) ; \mathrm{CTSF}_{6}=$ concentration of the $\mathrm{SF}_{6}$ in the exhaust air $\left(\mathrm{mg} / \mathrm{m}^{3}\right)$; and $\mathrm{CTNH}_{3}=$ concentration of $\mathrm{NH}_{3}$ in the exhaust air $\left(\mathrm{mg} / \mathrm{m}^{3}\right)$.

\section{Statistical Analysis of Urine and Slurry Composition}

The model used to analyze the data on urine composition was 
Table 4. Chemical composition and feeding value (VEM per $\mathrm{kg}$, others in $\mathrm{g} / \mathrm{kg}$ ) of compound concentrates ${ }^{1}$

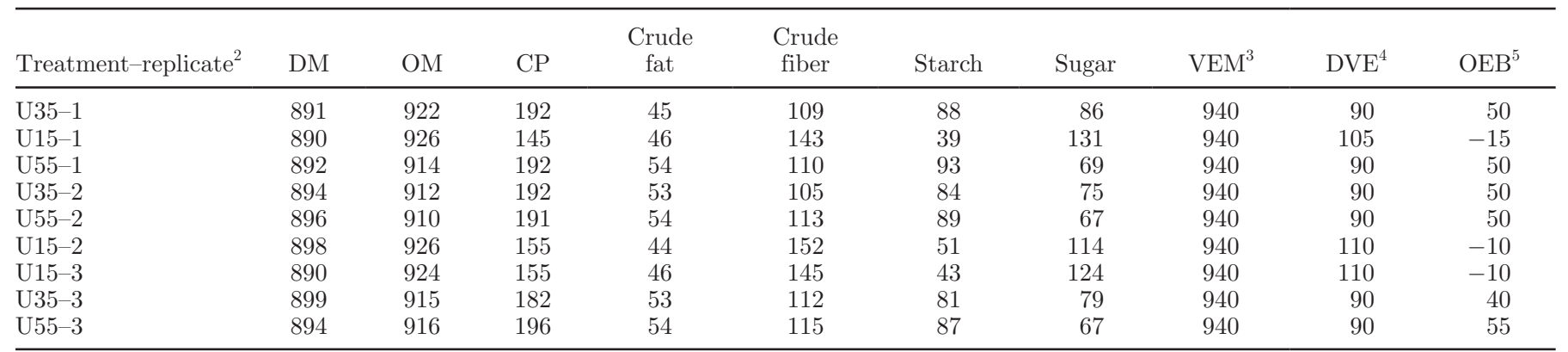

${ }^{1}$ Values provided by the feed manufacturer (Agrifirm, Meppel, the Netherlands).

${ }^{2}$ Treatments U15, U35, and U55 included 3 levels of 15, 35, and $55 \mathrm{mg}$ of urea per $100 \mathrm{~g}$ of milk, respectively.

${ }^{3} \mathrm{VEM}=\mathrm{NE}_{\mathrm{L}}$ according to Dutch standards.

${ }^{4} \mathrm{DVE}=$ true protein digested in the small intestine according to Dutch standards.

${ }^{5} \mathrm{OEB}=\mathrm{RDP}$ balance according to Dutch standards.

$Y=\mu+\beta+\tau+\beta \cdot \tau+b+b \cdot p+b \cdot p \cdot d+b \cdot p \cdot d \cdot t$,

where $Y$ is the response variable (total $\mathrm{N}$, urea-N, $\mathrm{pH}, \mathrm{Na}$, and $\mathrm{K}$, respectively), with the fixed terms $\mu$ (constant), $\beta$ (treatment effect; U15, U35, and U55, respectively), $\tau$ (time effect, a.m. or p.m.), $\beta \cdot \tau$ (treatment $\times$ time interaction) and the random terms $b$ (block $=$ replicate), $b \cdot p$ (period within block), $b \cdot p \cdot d$ (day within period within block, correlated autoregression, order 1), b.p.d.t (time within day within period within block; final residual error term).

The model used to analyze the data on both mixed slurry composition and composition of the top layer of the slurry was

$$
Y=\mu+\beta+b+b \cdot p,
$$

where $Y$ is the response variable (total $\mathrm{N}, \mathrm{NH}_{4}-\mathrm{N}$, and $\mathrm{pH}$, respectively), with the fixed terms $\mu$ (constant) and $\beta$ (treatment effect; U15, U35, and U55, respectively) and random terms $b$ (block $=$ replicate $)$ and $b \cdot p($ period within block; final residual error term).

The parameters of models [2] and [3] were estimated with REML in Genstat (Genstat 5 Committee, 1993), and the effects of treatment and time were tested using the Wald test.

\section{Dynamic Regression Analyses: Modeling}

The factors affecting $\mathrm{NH}_{3}$ emission from the barn were estimated using a dynamic regression model according to Pankratz (1991). The method used is largely similar to the modeling technique used by van Duinkerken et al. (2005). Statistical analyses were performed with emission data after logarithmic transformation. This transformation was based on general assumptions, which were checked retrospectively by an analysis of residues, as described by van Duinkerken et al. (2005). The first general assumption was that, by definition, concentrations have a positive value and are not normally distributed. Furthermore, with observations distributed over a large range, the observations at a relatively high level are more spread than observations at lower levels. A lognormal distribution is appropriate for such situations and data are normally distributed after log transformation. Furthermore, after log transformation, additive effects on a log scale become multiplicative on the original scale. A retrospective analysis of residues showed that a normal distribution of data on a $\log$ scale was valid and that a lognormal distribution on the original scale was appropriate.

In the study of van Duinkerken et al. (2005), the effect of bulk milk urea concentration on day $t$ was taken into account, as was the effect of bulk milk urea concentration on previous days. In the transfer functions, data on previous days were weighted according to an exponential decay model (Pankratz, 1991). Furthermore, it was assumed that repeated observations of the response variate were correlated and that this correlation can well be described by an autoregressive process of first order [AR(1)].

The model used in the current study is written as

$Y_{t}=C+\omega_{1} T_{t}+\frac{\omega_{21}}{1-\delta_{1} B} U_{t}+\frac{\omega_{22}}{1-\delta_{1} B} U_{t}^{2}+\frac{\omega_{3}}{1-\delta_{2} B} I_{t}+\frac{1}{1-\phi B} a_{t}$,

where $Y_{t}=\ln \left(\mathrm{NH}_{3, t}\right)$, natural logarithm of $\mathrm{NH}_{3}$ emission on day $t$, with emission in kilograms of $\mathrm{NH}_{3}$ per cow per $175 \mathrm{~d}$ (with $175 \mathrm{~d}$ being the average length of a grazing season in the Netherlands); $t=1, \ldots, 182 ; C$ $=$ constant; $T_{t}=$ outdoor temperature minus $15^{\circ} \mathrm{C}$, on 


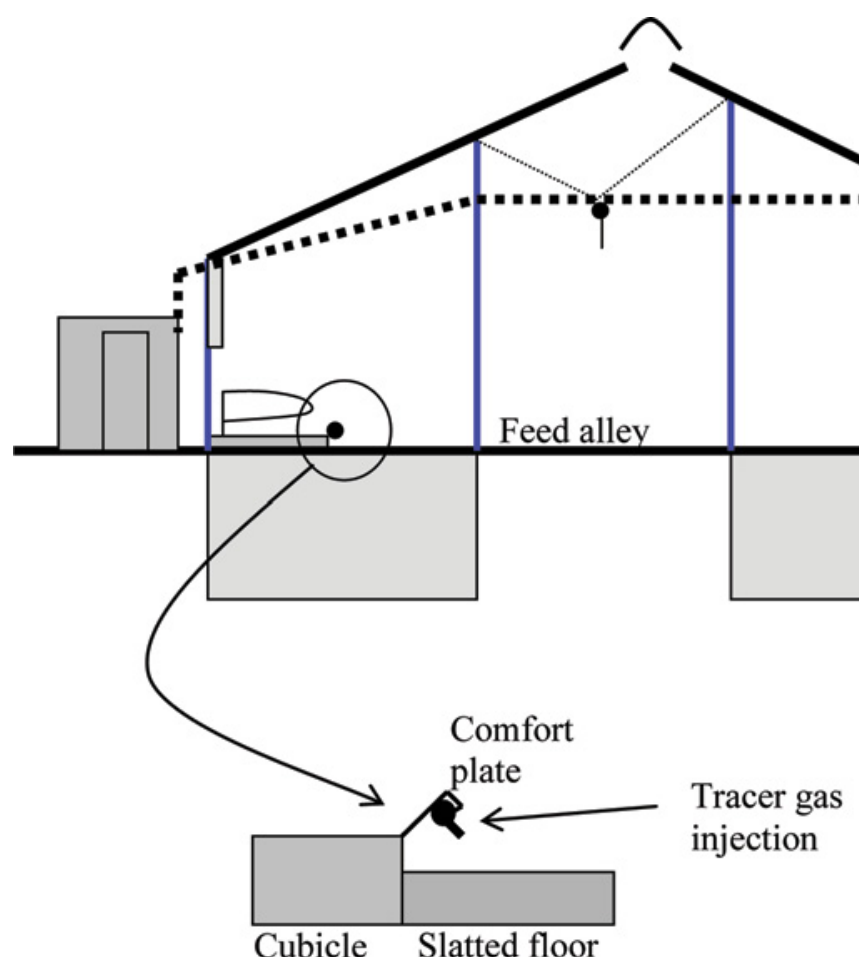

Figure 1. Cross section of the dairy cow barn and location of the tracer gas injection points. Color version available in the online PDF.

day $t ; U_{t}=$ milk urea concentration on day $t$, in $\mathrm{mg} / 100$ $\mathrm{g} ; I_{t}=$ index for slurry mixing on day $t$, where $I_{t}=0$ for no mixing and 1 for mixing; $\omega=$ regression parameters for the size of effects; $\delta=$ decay parameters; $\phi=$ autocorrelation coefficient for residual effects; $a_{t} \sim N\left(0, \sigma_{a}^{2}\right)$ $=$ random innovation effect with variance equal to $\sigma_{a}^{2}$; $B=$ backshift operator: $B X_{t}=X_{t-1}$, where $X_{t}=U_{t}, U_{t}^{2}$, $I_{t}$, or $a_{t}$.

Furthermore, the total variance of residual effects $\left(\sigma_{\text {res }}^{2}\right)$ was

$$
\sigma_{r e s}^{2}=\frac{\sigma_{a}^{2}}{1-\phi^{2}}
$$

and the percentage variance accounted for by the model is

$$
100\left(1-\frac{\sigma_{r e s}^{2}}{\sigma_{t o t}^{2}}\right),
$$

with $\sigma_{\text {tot }}^{2}$ being the total variance of the logarithmical transformed $\mathrm{NH}_{3}$ emission $Y_{t}$. Model [4] is fitted to the observed emission for the urea concentration in bulk milk.

\section{RESULTS}

\section{Milk Yield and Milk Fat and Protein}

In Table 5, milk yield and milk fat and protein percentages are given, all averaged for the last week of each treatment period. Also included in this table is the number of animals involved in milk recordings and milk sampling. The weighted averaged milk production level over the whole trial was $25.0 \mathrm{~kg} / \mathrm{d}$ with $4.49 \%$ fat and $3.33 \%$ protein.

\section{Milk Urea Content}

The development of the expected and actual urea concentrations in bulk milk during the course of the experiment is illustrated in Figure 2. The intended dispersion in bulk milk urea level ( 15 to $55 \mathrm{mg}$ of urea per $100 \mathrm{~g}$ of milk) was achieved; some samples contained less than $15 \mathrm{mg}$ of urea per $100 \mathrm{~g}$ of milk. The highest level of $55 \mathrm{mg} / 100 \mathrm{~g}$ was only achieved at one sampling moment and, especially in U55-1 and U55-2, actual milk urea levels were lower than targeted. The course of the actual milk urea data was more irregular than the expected course, which was not surprising because of the variable grazing conditions (i.e., composition and intake of pasture grass) and because of random variance of MUN determination (Broderick, 2003; Kohn et al., 2004). 
Table 5. Milk yield and milk composition in the last week per treatment replicate and number of animals involved in milk recordings and milk sampling

\begin{tabular}{lcccc}
\hline Treatment-replicate $^{1}$ & Animals $^{2}$ & $\begin{array}{c}\text { Milk } \\
(\mathrm{kg} / \mathrm{d})\end{array}$ & $\begin{array}{c}\text { Fat } \\
(\%)\end{array}$ & $\begin{array}{c}\text { Protein } \\
(\%)\end{array}$ \\
\hline U35-1 & 49 & 26.2 & 4.48 & 3.21 \\
U15-1 & 50 & 28.4 & 4.31 & 3.37 \\
U55-1 & 45 & 25.9 & 4.33 & 3.22 \\
U35-2 & 46 & 25.6 & 4.52 & 3.31 \\
U55-2 & 48 & 25.6 & 4.37 & 3.28 \\
U15-2 & 51 & 23.1 & 4.44 & 3.51 \\
U15-3 & 51 & 23.4 & 4.56 & 3.43 \\
U35-3 & 47 & 22.5 & 4.46 & 3.33 \\
U55-3 & 46 & 22.1 & 4.63 & \\
\hline
\end{tabular}

${ }^{1}$ Treatments U15, U35, and U55 included 3 levels of 15, 35, and $55 \mathrm{mg}$ of urea per $100 \mathrm{~g}$ of milk, respectively. ${ }^{2}$ Number of animals involved in the milk recording and milk sampling; the whole treatment group generally included some more animals (e.g., heavily pregnant animals).

Herd milk urea concentration per milking is displayed in Figure 3, with a.m. and p.m. milkings shown separately. Average urea concentration in bulk milk was $31.4 \pm 11.4 \mathrm{mg} / 100 \mathrm{~g}$ of milk for the whole experiment. Average urea concentrations in herd milk for the whole experiment were $33.6 \pm 11.5$ and $30.3 \pm 13.4$ $\mathrm{mg} / 100 \mathrm{~g}$ for $\mathrm{p} . \mathrm{m}$. and a.m. milkings, respectively. The general development in herd milk urea concentration in time resembled that in bulk milk urea concentration, but the variation in herd milk urea concentration was higher than that in bulk milk urea concentration (Figure 3).

\section{Urine and Slurry Composition}

Data on urine composition were averaged per treatment per sampling time, as shown in Table 6 . The concentrations of total $\mathrm{N}$, urea-N, and $\mathrm{Na}$ in urine increased with increasing adjusted milk urea levels. Furthermore, levels of total $\mathrm{N}$, urea- $\mathrm{N}$, and $\mathrm{K}$ in urine were higher in a.m. than in p.m. sampling times, whereas Na concentration in urine was higher for p.m. sampling than for a.m. sampling.

The composition of the top layer of the slurry in the pit in the third week of each treatment was averaged per

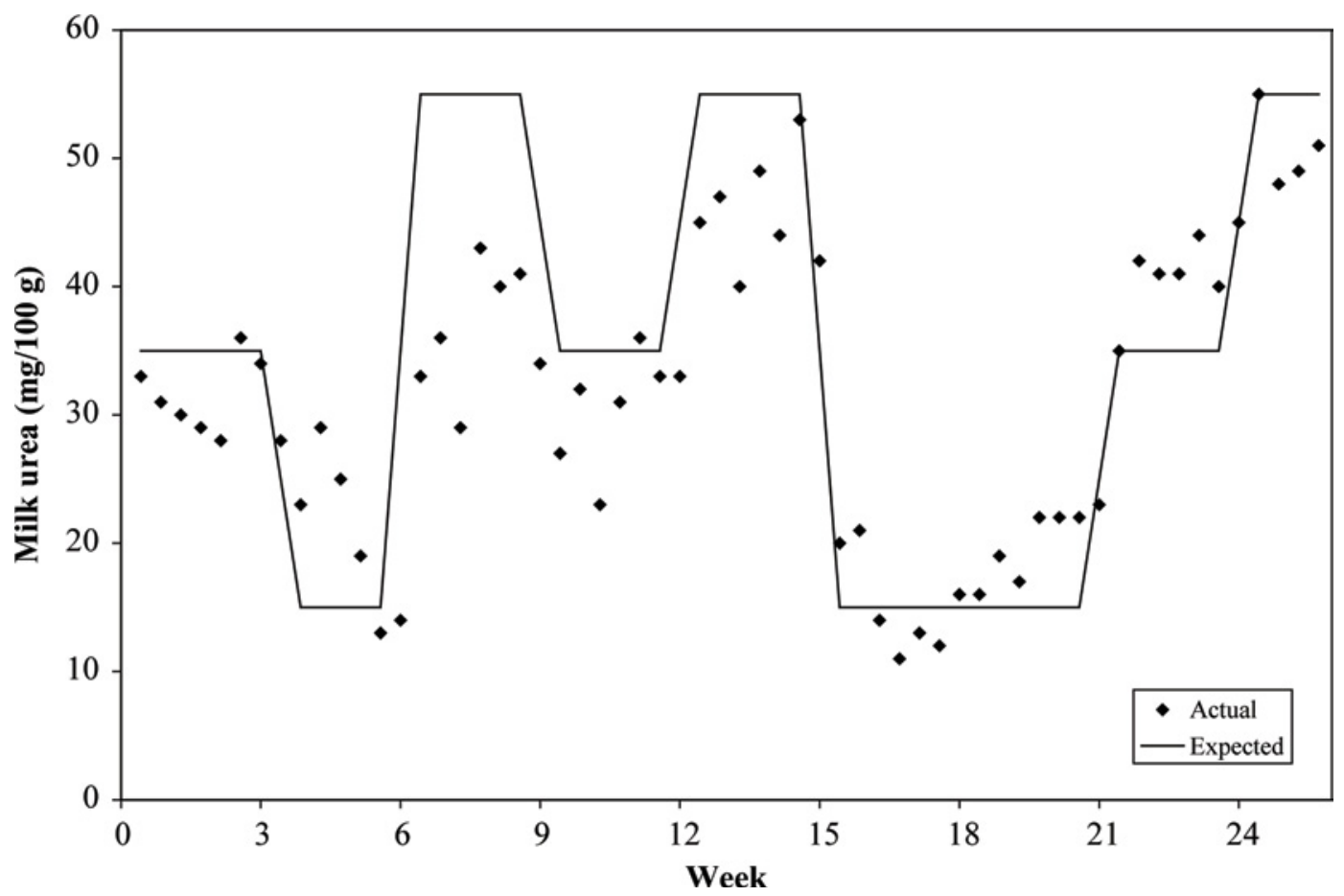

Figure 2. Development of the actual and expected bulk milk urea concentration $(\mathrm{mg} / 100 \mathrm{~g})$ during the course of the experiment. 
treatment and is presented in Table 7. Total N, $\mathrm{NH}_{4}-\mathrm{N}$, and $\mathrm{pH}$ in the top layer of the slurry were higher with higher levels of adjusted milk urea. The data on mixed slurry composition in the third week of each treatment were averaged per treatment and are presented in Table 8. Concentration of $\mathrm{NH}_{4}-\mathrm{N}$ was higher with higher levels of adjusted milk urea, whereas DM content of the mixed slurry was lower with higher levels of adjusted milk urea. The concentration of $\mathrm{K}$ in mixed slurry was highest for U55.

\section{Ammonia Emission}

Figure 4 shows the development of daily averaged $\mathrm{NH}_{3}$ emission, barn temperature, and outdoor temperature; considerable day-to-day variation in $\mathrm{NH}_{3}$ emission was observed. Some $\mathrm{NH}_{3}$ emission values could not be collected during the last 2 wk of September because of technical malfunctioning of the emission measurement equipment. The observed $\mathrm{NH}_{3}$ emission was correlated with temperature.

\section{Emission Model}

A dynamic regression model for $\mathrm{NH}_{3}$ emission from the barn was derived based on outdoor temperature and bulk milk urea concentration. First, the general dynamic regression model [4] was adjusted to the logarithm of the $\mathrm{NH}_{3}$ emission data. Genstat (Genstat 5 Committee, 1993) was used to calculate the auto-correlation function and the partial auto-correlation function for the residuals of the $\mathrm{AR}(1)$ model.

The parameter estimates and standard error per parameter of the fitted emission model are given in Table 9. The model accounted for $66 \%$ of the variance in $\mathrm{NH}_{3}$ emission. The emission model showed that $\mathrm{NH}_{3}$ emission increased 2.6\% when outdoor temperature increased by $1^{\circ} \mathrm{C}$. Furthermore, emission increased exponentially with increasing milk urea concentration. At a level of $20 \mathrm{mg}$ of urea per $100 \mathrm{~g}$ of milk, $\mathrm{NH}_{3}$ emission increased $2.5 \%$ when milk urea concentration increased by $1 \mathrm{mg} / 100 \mathrm{~g}$. At a level of $30 \mathrm{mg}$ of urea per $100 \mathrm{~g}$ of milk, $\mathrm{NH}_{3}$ emission increased $3.5 \%$ when milk urea concentration increased by $1 \mathrm{mg} / 100 \mathrm{~g}$. Finally, it appears that mixing of the slurry immediately followed by pumping it to another slurry storage outside the barn increased $\mathrm{NH}_{3}$ emission by $11 \%$ on the day of mixing. This effect disappeared rapidly in the next few days.

Figure 5 illustrates the calculated median $\mathrm{NH}_{3}$ emission, the lower and upper limits of the $95 \%$ confidence interval for the expected emission, and the $95 \%$ confidence interval for the individual emission data.

\section{DISCUSSION}

\section{Emission Models}

Several $\mathrm{NH}_{3}$ emission models for dairy farms have been developed, especially during the last decade. Some models have attempted to describe emissions on the farm level, including animal housing, slurry storage, slurry application, and grazing (Pinder et al., 2004; Schils et al., 2007), whereas others focused on emissions from naturally ventilated dairy barns (Monteny et al., 2002; Wang et al., 2005) or tie-stall chambers (Powell et al., 2008b). Sommer et al. (2006) reviewed the literature focusing on the $\mathrm{NH}_{3}$ emissions from buildings housing livestock, impermeable yard areas, and manure storage. They modeled both the processes of $\mathrm{NH}_{3}$ release from manure and the transport of $\mathrm{NH}_{3}$ in animal houses.

In this study, the applicability of bulk milk urea as an indicator for $\mathrm{NH}_{3}$ emission from the dairy barn was assessed, because this parameter is available as a management tool in common practice.

\section{Emission Model Parameters}

This study showed that $\mathrm{NH}_{3}$ emission from a dairy barn could be estimated with $66 \%$ of variance accounted for using a model with bulk milk urea content, outdoor temperature, and a slurry mixing parameter. To model the correlation between milk urea concentration and $\mathrm{NH}_{3}$ emission, several treatments were formulated to create a wide range of milk urea data. To increase the power of the emission model, some additional variables were incorporated into the model. Temperature and slurry mixing and handling had a significant and large effect on $\mathrm{NH}_{3}$ emissions and therefore were included in the emission model.

The effects of temperature and slurry handling correspond with the effects found by van Duinkerken et al. (2005) in the same barn with cows kept indoors for $24 \mathrm{~h} / \mathrm{d}$. As it is not common practice to mix and pump slurry every 3 wk during the grazing season, it is assumed that the slurry mixing parameter $I_{t}=0$ under practical conditions.

\section{Variability in Milk Urea Levels}

For modeling purposes, milk urea concentration was forced to levels varying between approximately 15 and $55 \mathrm{mg} / 100 \mathrm{~g}$ of milk. However, to develop an emission model based on a dynamic regression approach, it is not necessary to achieve the exact milk urea levels that were expected based on diet composition. This discrepancy was taken into account when the experiment was 
Table 6. Urine composition, averaged per treatment per sampling time

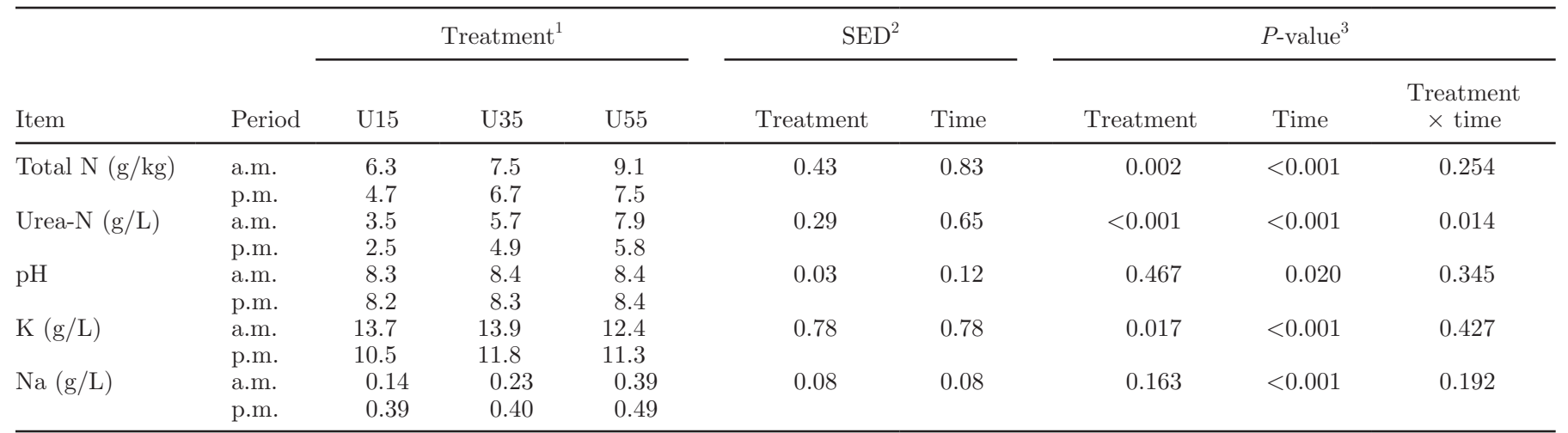

${ }^{1}$ Treatments U15, U35, and U55 included 3 levels of 15, 35, and $55 \mathrm{mg}$ of urea per $100 \mathrm{~g}$ of milk, respectively.

${ }^{2}$ Standard error of differences for the same level of factor, respectively, for the fixed terms treatment and time.

${ }^{3} P$-value (chi probability) based on Wald test for the fixed terms treatment and time.

designed. It was assumed a priori that large day-to-day variability in MUN would occur (Rajala-Schultz and Saville, 2003), particularly because of fluctuations in pasture grass composition, feed intake, and grazing conditions. Furthermore, deviations between expected and actual milk urea concentration (Figures 2 and 3) were anticipated. The targeted range of 15 to $55 \mathrm{mg}$ of urea per $100 \mathrm{~g}$ of milk was achieved in the experiment.
In common practice, farmers have only bulk milk urea concentration available as management information; therefore, bulk milk is the most practical base for the development of a management tool. In this experiment, as in common Dutch dairying practice, the milk bulk tank was emptied every 3 d (generally after 6 milkings). Clear milking-to-milking variation in milk urea concentration was observed within one milk delivery period of $3 \mathrm{~d}$ (Figure 3 ). In this study, the p.m. milking

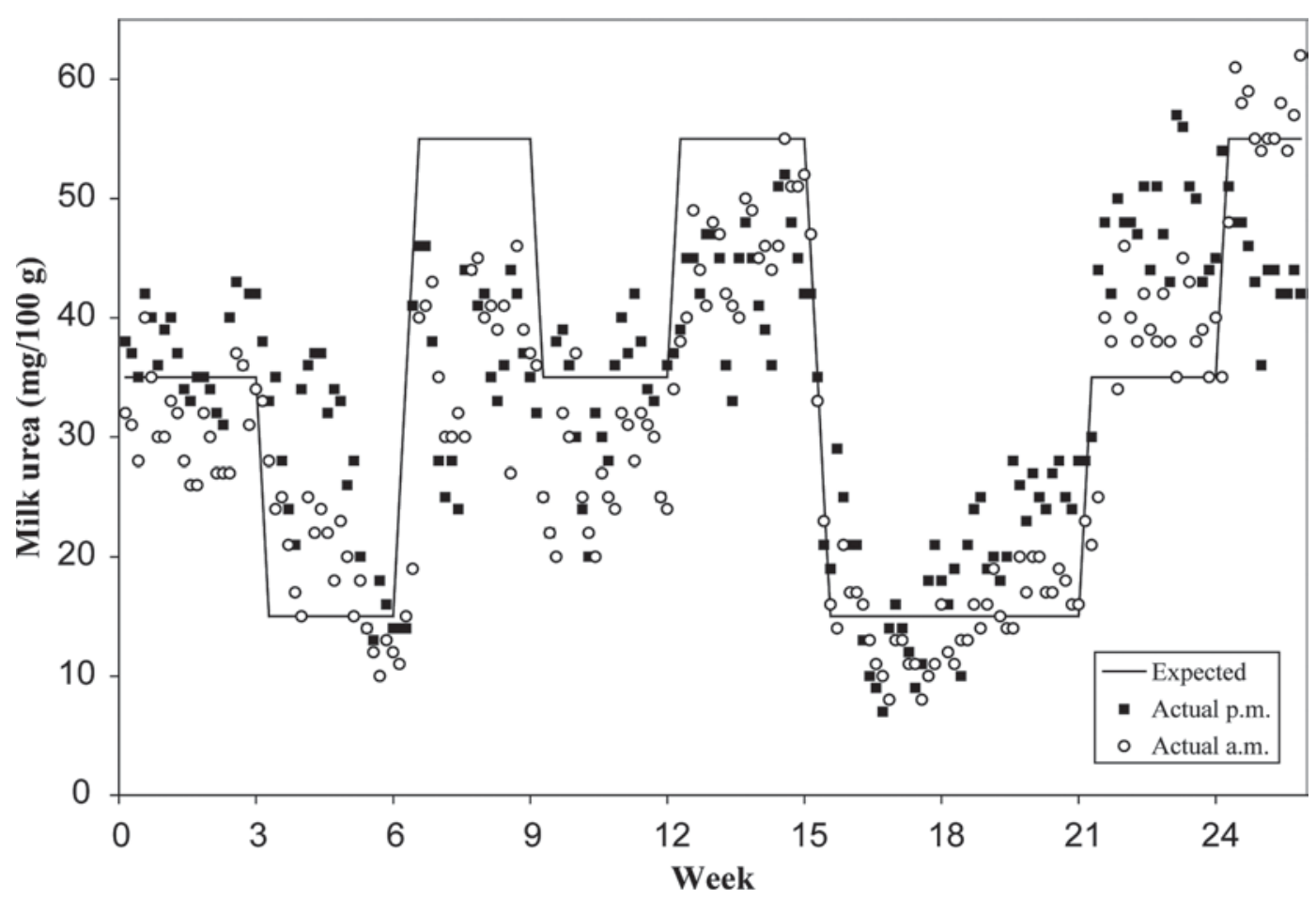

Figure 3. Development of actual and expected milk urea concentration (mg/100 g) per a.m. and p.m. milking during the course of the experiment. 


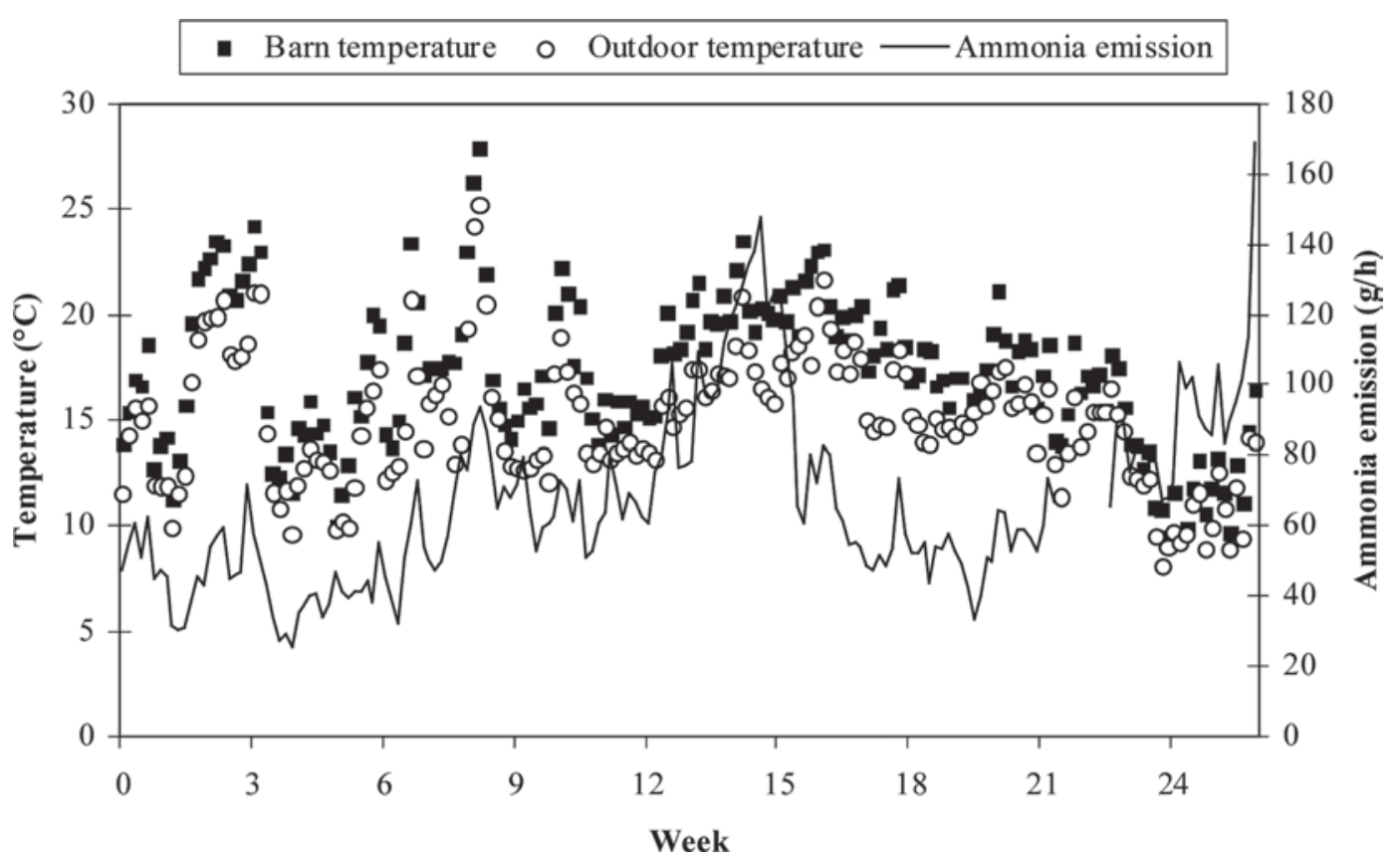

Figure 4. Averaged daily ammonia emission $(\mathrm{g} / \mathrm{h})$ from the barn, barn temperature $\left({ }^{\circ} \mathrm{C}\right)$ and outdoor temperature $\left({ }^{\circ} \mathrm{C}\right)$.

generally showed a higher milk urea concentration than the a.m. milking. This is common in situations with restricted grazing when N-rich pasture grass is grazed during daytime and cows are supplemented in the barn between the p.m. and a.m. milking with feedstuffs that have a smaller $\mathrm{N}$ content than grass.

\section{Urine Composition}

Data on urine composition (Table 6) illustrate that the concentrations of both total $\mathrm{N}$ and urea- $\mathrm{N}$ increased with increasing adjusted milk urea levels. This positive correlation corresponds with the physiological process of urea, formed in the liver and secreted in blood plasma, diffusing to other body fluid pools such as milk (Gustafsson and Palmquist, 1993), saliva, and rumen liquid (Huntington and Archibeque, 1999) and being (actively) excreted in the urine via the kidneys (Burgos et al., 2007). Therefore, it is generally assumed that an increase in plasma urea nitrogen (PUN) concentration leads to higher levels of MUN and increased excretion of urinary urea nitrogen (UUN).

From the data on urine composition in Table 6, it appears that diurnal variation in total $\mathrm{N}$, urea- $\mathrm{N}, \mathrm{K}$, and $\mathrm{Na}$ concentrations exists. Total $\mathrm{N}$, urea- $\mathrm{N}$, and $\mathrm{K}$ concentrations were higher at the a.m. than at the p.m. sampling time, whereas Na concentration in urine was higher for p.m. sampling than for a.m. sampling. Gustafsson and Palmquist (1993) also found clear diurnal variations in MUN and PUN concentrations, with MUN concentrations reaching peak values around $4 \mathrm{~h}$ after a meal. Furthermore, the study of Broderick and Clayton (1997) demonstrated that sampling time influences the MUN-UUN relationship. In their study, different relationships were found between BUN and MUN when assessed from MUN in milk collected at either the a.m. or p.m. milking; BUN was more highly correlated with mean daily MUN concentration. In general, level

Table 7. Composition of the top layer in the slurry pit in the third week of each treatment period, averaged per treatment

\begin{tabular}{|c|c|c|c|c|c|}
\hline \multirow[b]{2}{*}{ Item } & \multicolumn{3}{|c|}{ Treatment $^{1}$} & \multirow[b]{2}{*}{$\mathrm{SED}^{2}$} & \multirow[b]{2}{*}{$P$-value ${ }^{3}$} \\
\hline & U15 & U35 & U55 & & \\
\hline Total-N (g/kg) & 4.23 & 4.69 & 4.94 & 0.115 & $<0.001$ \\
\hline $\mathrm{NH}_{4}-\mathrm{N}(\mathrm{g} / \mathrm{kg})$ & 1.44 & 1.76 & 1.96 & 0.100 & $<0.001$ \\
\hline $\mathrm{pH}$ & 6.9 & 7.1 & 7.1 & 0.04 & $<0.001$ \\
\hline
\end{tabular}

${ }^{1}$ Treatments U15, U35, and U55 included 3 levels of 15, 35, and $55 \mathrm{mg}$ of urea per $100 \mathrm{~g}$ of milk, respectively.

${ }^{2}$ Standard error of the difference.

${ }^{3} P$-value (chi probability) based on Wald test. 
Table 8. Composition of the mixed slurry in the third week of each treatment period, averaged per treatment

\begin{tabular}{|c|c|c|c|c|c|}
\hline \multirow[b]{2}{*}{ Item } & \multicolumn{3}{|c|}{ Treatment $^{1}$} & \multirow[b]{2}{*}{$\mathrm{SED}^{2}$} & \multirow[b]{2}{*}{$P$-value ${ }^{3}$} \\
\hline & U15 & U35 & U55 & & \\
\hline Total-N ( $\mathrm{g} / \mathrm{kg})$ & 3.80 & 3.83 & 3.86 & 0.045 & 0.41 \\
\hline $\mathrm{NH}_{4}-\mathrm{N}(\mathrm{g} / \mathrm{kg})$ & 2.03 & 2.11 & 2.21 & 0.020 & $<0.001$ \\
\hline $\mathrm{pH}$ & 7.6 & 7.5 & 7.7 & 0.07 & 0.24 \\
\hline $\mathrm{DM}(\mathrm{g} / \mathrm{kg})$ & 68.4 & 65.4 & 61.8 & 1.74 & 0.001 \\
\hline $\mathrm{Na}(\mathrm{g} / \mathrm{kg})$ & 0.55 & 0.62 & 0.59 & 0.073 & 0.58 \\
\hline $\mathrm{K}(\mathrm{g} / \mathrm{kg})$ & 4.83 & 4.82 & 5.01 & 0.026 & $<0.001$ \\
\hline
\end{tabular}

${ }^{1}$ Treatments U15, U35, and U55 included 3 levels of 15, 35, and $55 \mathrm{mg}$ of urea per $100 \mathrm{~g}$ of milk, respectively.

${ }^{2}$ Standard error of the difference.

${ }^{3} P$-value (chi probability) based on Wald test.

of feed intake, feed composition, feed intake pattern, milking frequency, and urinating behavior are major factors affecting diurnal variations in PUN, MUN, and UUN and their interrelations.

Data in Table 6 also indicate that the ratio between urea- $\mathrm{N}$ and total $\mathrm{N}$ was affected by treatment. This ratio was approximately $55 \%$ for U15 and it increased as adjusted milk urea levels were higher. The highest ratio (approximately 87\%) was achieved at the a.m. sampling time for U55.

\section{Slurry Composition}

Differences in composition of mixed slurry between treatments were rather limited (Table 8). The concentration of $\mathrm{NH}_{4}-\mathrm{N}$ in the slurry was lowest for U15 and highest for U55, although differences were rather small. It should be taken into account that at the end of a 3 -wk treatment period about $80 \%$ of the slurry volume in the pit originates form previous treatments. This indicates that treatment effects on mixed slurry composition are leveled out, to a great extent. However, total $\mathrm{N}$ and urea- $\mathrm{N}$ levels in urine (Table 6) are strongly influenced by diet (treatment), thus affecting total $\mathrm{N}$ and $\mathrm{NH}_{4}-\mathrm{N}$ concentration in the top layer of the slurry in the pit (Table 7). It should be noted that the top layer of slurry is not a homogeneous fraction because of differences in gravity between urine and solid feces components. van der Stelt et al. (2008) studied the effects of dietary protein and energy levels on cow manure excretion and calculated ammonia volatilization. In their experiment, they had no interference of older manure in the slurry pit, enabling them to examine thoroughly the correlation between diet and manure characteristics. van der Stelt et al. (2008) found that increasing the CP content of the feed (108 to $190 \mathrm{~g} / \mathrm{kg}$ of DM) resulted in an average increase in total $\mathrm{N}$ content of the slurries of $56 \%$. Total ammonia nitrogen amounted to 52 to $77 \%$ of the total $\mathrm{N}$ content present in manure slurries. A low $\mathrm{CP}$ content of diets reduced total ammonia $\mathrm{N}$ concentrations in the slurries by $43 \%$. In agreement with the calculated aqueous $\mathrm{NH}_{3}$ content, the total amount of $\mathrm{NH}_{3}$ volatilized from manure slurries was much greater (on average 10 times greater) when the cows were fed greater levels of $\mathrm{CP}$.

\section{Emission Reduction Potential}

The similarity of results between the study of van Duinkerken et al. (2005) (summer feeding experiment) and the present study (restricted grazing experiment) confirms that feeding measures have high potential to reduce $\mathrm{NH}_{3}$ emission and that bulk milk urea is a useful indicator for $\mathrm{NH}_{3}$ emission reduction. These conclusions are supported by several studies in which positive relationships were found between (1) dietary CP concentration, MUN, and urinary $\mathrm{N}$ excretion (Kebreab et al., 2002; Nousiainen et al., 2004; Burgos et al., 2007);

Table 9. Estimates and SE for the parameters of the emission model [4] and variance components of the model

\begin{tabular}{lcl}
\hline Parameter $^{1}$ & Estimate & \multicolumn{1}{c}{ SE } \\
\hline$C$ & 1.25 & 0.20 \\
$\omega_{1}$ & 0.026 & 0.006 \\
$\delta_{1}$ & 0.85 & 0.05 \\
$\omega_{21}$ & $-0.0013^{2}$ & 0.0022 \\
$\omega_{22}$ & 0.000088 & 0.000042 \\
$\delta_{2}$ & 0.45 & 0.49 \\
$\omega_{3}$ & 0.11 & 0.06 \\
$\phi$ & 0.72 & 0.06 \\
$\sigma_{a}^{2}$ & 0.0216 & - \\
$\sigma_{\text {tot }}^{2}$ & 0.044 & - \\
$\sigma^{2}$ & 0.130 & - \\
\hline
\end{tabular}

${ }^{1} C=$ constant; $\omega=$ regression parameter for the size of effects; $\delta=$ decay parameter; $\phi=$ autocorrelation coefficient for residual effects; $\sigma_{a}^{2}=$ variance of random innovation effect; $\sigma_{\text {tot }}^{2}=$ the total variance of the logarithmical transformed $\mathrm{NH}_{3}$ emission; $\sigma^{2}=$ the total variance of residual effects.

${ }^{2}$ Parameter estimate not different from zero, based on a $t$-test. 


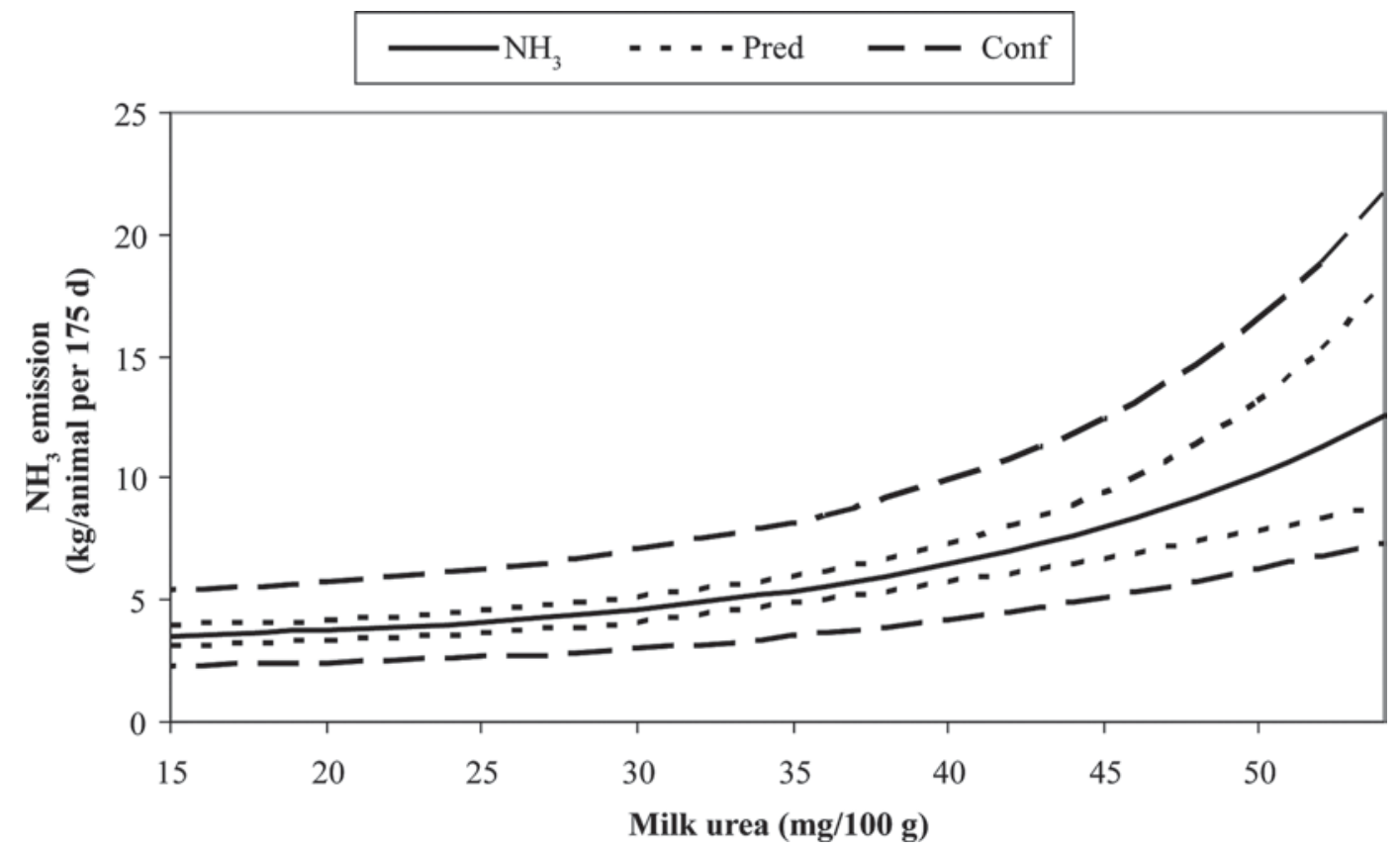

Figure 5. Median ammonia emission $\left(\mathrm{NH}_{3}\right)$, 95\% CI for individual emission (Conf), and 95\% CI (Pred) for the expected emission based on model [4] $\left(\mathrm{NH}_{3}\right.$ emission in $\mathrm{kg} /$ animal per $175 \mathrm{~d}$; bulk milk urea in $\left.\mathrm{mg} / 100 \mathrm{~g}\right)$, standardized for outdoor temperature of $15^{\circ} \mathrm{C}$ and $I_{t}=0\left(I_{t}=\right.$ index for slurry mixing on day $t$, where $I_{t}=0$ for no mixing and 1 for mixing).

(2) urinary $\mathrm{N}$ excretion and $\mathrm{NH}_{3}$ emission (Smits et al., 1995; Monteny et al., 1998; Cassel et al., 2005); and (3) MUN and $\mathrm{NH}_{3}$ emission (Frank and Swensson, 2002; Powell et al., 2008a).

In the Netherlands, the national average milk urea concentration decreased from 30 to $25 \mathrm{mg} / 100 \mathrm{~g}$ of milk over the period 1998 to 2001 (van Duinkerken et al., 2005), corresponding with a decrease of MUN from 14.4 to $12.0 \mathrm{mg} / 100 \mathrm{~mL}$. This reduction in MUN indicates that farmers were able to reduce $\mathrm{NH}_{3}$ emissions from dairy barns with about $12.5 \%$ on average over this period (van Duinkerken et al., 2005). In various other European studies with varying circumstances (Cottrill et al., 2002; González Rodríguez and Vázquez Yánez, 2002; Nousiainen et al., 2004), milk urea levels were reported that are clearly above $18 \mathrm{mg} / 100 \mathrm{~g}$ milk $(=8.6$ $\mathrm{mg}$ of MUN/100 mL of milk). This level is the benchmark for optimal bulk milk urea concentration when the results of Schepers and Meijer (1998) are evaluated for a situation with feeding according energy and protein requirements and an RDP balance of $0 \mathrm{~g} / \mathrm{d}$. Taking into account the levels of milk urea in various European Union regions, high potential exists for further reduction of $\mathrm{NH}_{3}$ emission by nutritional measures.

\section{CONCLUSIONS}

The emission of $\mathrm{NH}_{3}$ from a naturally ventilated dairy cow barn in a situation with restricted grazing was strongly influenced by both temperature and diet. Reduction of $\mathrm{NH}_{3}$ emission was predicted adequately (66\% of variance accounted for) by a dynamic regression model using bulk milk urea concentration, outdoor temperature, and a slurry mixing parameter as explanatory variates. This study demonstrates that, in common dairy farming practice, $\mathrm{NH}_{3}$ emission reduction can be monitored and controlled using milk urea concentration as an indicator. Ammonia emission increased exponentially with increasing milk urea concentration. At a level of 20 or $30 \mathrm{mg}$ of urea per $100 \mathrm{~g}$ of milk, $\mathrm{NH}_{3}$ emission increased 2.5 and $3.5 \%$, respectively, when milk urea concentration increased by $1 \mathrm{mg} / 100 \mathrm{~g}$. In this study daily averaged outdoor temperature ranged from 8 to $25^{\circ} \mathrm{C}$ and ammonia emission from the barn increased with approximately $2.6 \%$ when outdoor temperature increased with $1^{\circ} \mathrm{C}$. Taking into account the current European levels of milk urea, there is a rather high potential for further reduction of $\mathrm{NH}_{3}$ emission by feeding measures.

\section{ACKNOWLEDGMENTS}

This study was financed by the Dutch Ministry of Agriculture, Nature and Food Quality (the Hague, the Netherlands) and the Dutch Dairy Board (Zoetermeer, the Netherlands). The authors thank Gerard Verkade, Gerard de Bree, Henk Gunnink, Klaas Blanken, GertJan Monteny, Martin Wagemans, and Pieter Vereijken 
(all Wageningen UR, Wageningen, the Netherlands) for their involvement in the study. Furthermore, we thank the members of the feed back group for their technical advice.

\section{REFERENCES}

Andersson, M. 1994. A climate chamber for measuring ammonia emission. Pages 499-506 in Proc. XII World Congress on Agricultural Engineering, Milan, Italy. Commission of Agricultural Engineering, Merelbeke, Belgium.

Broderick, G. A. 2003. Effects of varying dietary protein and energy levels on the production of lactating dairy cows. J. Dairy Sci. 86:1370-1381

Broderick, G. A., and M. K. Clayton. 1997. A statistical evaluation of animal and nutritional factors influencing concentrations of milk urea nitrogen. J. Dairy Sci. 80:2964-2971.

Burgos, S. A., J. G. Fadel, and E. J. DePeters. 2007. Prediction of ammonia emission from dairy cattle manure based on milk urea nitrogen: Relation of milk urea nitrogen to urine urea nitrogen excretion. J. Dairy Sci. 90:5499-5508.

Bussink, D. W., and O. Oenema. 1998. Ammonia volatilization from dairy farming systems in temperate areas: A review. Nutr. Cycl. Agroecosyst. 51:19-33.

Cassel, T., L. Ashbaugh, and R. Flocchini. 2005. Ammonia emission factors for open-lot dairies: Direct measurements and estimation by nitrogen intake. J. Air Waste Manag. Assoc. 55:826-833.

CBGV. 1998. Commission on Fertilization of Grassland and Forage Crops. Adviesbasis bemesting grassland en voedergewassen. PR, Lelystad, the Netherlands.

Cottrill, B., H. J. Biggadike, C. Collins, and R. A. Laven. 2002. Relationship between milk urea concentration and the fertility of dairy cows. Vet. Rec. 151:413-416.

CVB. 2002. Tabellenboek Veevoeding 2002. Voedernormen landbouwhuisdieren en voederwaarde veevoeders. [Dutch feeding tables 2002]. Central Bureau for Livestock Feeding, Lelystad, the Netherlands.

CVB. 2003. Handleiding Voederwaardeberekening Ruwvoeders. [Manual for feed evaluation of forages]. Central Bureau for Livestock Feeding, Lelystad, the Netherlands.

De Campeneere, S., D. L. De Brabander, and J. M. Vanacker. 2006. Milk urea concentration as affected by the roughage type offered to dairy cattle. Livest. Sci. 103:30-39.

de Jong, E. A. M., H. Klomp, G. Ellen, and H. van Hemert. 1992. Evaluation of a segmented-flow method for the routine determination of urea in milk. Neth. Milk Dairy J. 46:115-122.

Demmers, T. G. M., L. R. Burgess, V. R. Phillips, J. A. Clark, and C. M. Wathes. 2000. Assessment of techniques for measuring the ventilation rate, using an experimental building section. J. Agric. Eng. Res. 76:71-81.

Demmers, T. G. M., V. R. Phillips, L. S. Short, L. R. Burgess, R. P. Hoxey, and C. M. Wathes. 2001. Validation of ventilation rate measurement methods and ammonia emission from naturally ventilated dairy and beef buildings in the United Kingdom. J. Agric. Eng. Res. 79:107-116.

European Union. 2001. Directive 2001/81/EC of the European Parliament and of the Council of 23 October 2001 on national emission ceilings for certain atmospheric pollutants. Off. J. Eur. Commun. 27.11 .2001

Frank, B., and C. Swensson. 2002. Relationship between content of crude protein in rations for dairy cows and milk yield, concentration of urea in milk and ammonia emissions. J. Dairy Sci. 85:1829-1838.

Genstat 5 Committee. 1993. Genstat 5, release 3, Reference Manual. AFRC Institute of Arable Crops Research, Harpenden, UK. Oxford University Press, Oxford, UK.

González Rodríguez, A., and O. P. Vázquez Yáñez. 2002. Milk urea content on supplemented grazing dairy cows in Galicia. Lowland and Grasslands of Europe: Utilization and Development. G. Fisher and B. Frankow-Lindberg, ed. FAO/CIHEAM Interregional and Cooperative Research and Development Network on Pastures and Fodder Crop Production; Lowland Grasslands Subnetwork. Food and Agriculture Organization of the United Nations, Rome, Italy. http://www.fao.org/docrep/006/ad236e/ad236e00.htm

Gustafsson, A. H., and D. L. Palmquist. 1993. Diurnal variation of rumen ammonia, serum urea, and milk urea in dairy cows at high and low yields. J. Dairy Sci. 76:475-484.

Huntington, G. B., and S. L. Archibeque. 1999. Practical aspects of urea and ammonia metabolism in ruminants. J. Anim. Sci. 77:111.

International Organization for Standardization (ISO). 2000. General requirements for the competence of testing and calibration laboratories (EN ISO/IEC 17025:1999). CEN/CENELEC, Brussels, Belgium.

James, T., D. Meyer, E. Esparza, E. J. Depeters, and H. Perez-Monti. 1999. Effects of dietary nitrogen manipulation on ammonia volatilization from manure from Holstein heifers. J. Dairy Sci. 82:2430-2439.

Kauffman, A. J., and N. R. St-Pierre. 2001. The relationship of milk urea nitrogen to urine nitrogen excretion in Holstein and Jersey cows. J. Dairy Sci. 84:2284-2294.

Kebreab, E., J. France, J. A. Mills, R. Allison, and J. Dijkstra. 2002. A dynamic model of $\mathrm{N}$ metabolism in the lactating dairy cow and an assessment of impact of $\mathrm{N}$ excretion on the environment. J. Anim. Sci. 80:248-259.

Kohn, R. A., K. R. French, and E. Russek-Cohen. 2004. A comparison of instruments and laboratories used to measure milk urea nitrogen in bulk-tank milk samples. J. Dairy Sci. 87:1848-1853.

Kohn, R. A., K. F. Kalscheur, and E. Russek-Cohen. 2002. Evaluation of models to estimate urinary nitrogen and expected milk urea nitrogen. J. Dairy Sci. 85:227-233.

Kroodsma, W., J. W. H. Huis in t'Veld, and R. Scholtens. 1993. Ammonia emission and its reduction from cubicle houses by flushing. Livest. Prod. Sci. 35:293-302.

Lascano, G. J., G. I. Zanton, M. L. Moody, P. A. Topper, E. F. Wheeler, and A. J. Heinrichs. 2008. Short communication: Effect of changing the ratio of forage to concentrate on ammonia emissions by dairy heifers. J. Dairy Sci. 91:4301-4306.

Marik, T., and I. Levin. 1996. A new tracer experiment to estimate the methane emissions from a dairy cow shed using sulphur hexafluoride. Global Biogeochem. Cycles 10:413-418.

Misselbrook, T. H., J. M. Powell, G. A. Broderick, and J. H. Grabber. 2005. Dietary manipulation in dairy cattle: Laboratory experiments to assess the influence on ammonia emissions. J. Dairy Sci. $88: 1765-1777$.

Monteny, G. J. 2000. Modeling of ammonia emissions from dairy cow houses. PhD Thesis. Report 2000-11. Institute of Agricultural and Environmental Engineering, Wageningen University, Wageningen, the Netherlands.

Monteny, G. J., and J. W. Erisman. 1998. Ammonia emission from dairy cow buildings: A review of measurement techniques, influencing factors and possibilities for reduction. Neth. J. Agric. Sci. $46: 225-247$.

Monteny, G. J., D. D. Schulte, A. Elzing, and E. J. J. Lamaker. 1998. A conceptual mechanistic model for the ammonia emissions from free-stall cubicle dairy cow houses. Trans. ASAE 41:193-201.

Monteny, G. J., M. C. J. Smits, G. van Duinkerken, H. Mollenhorst, and I. J. M. de Boer. 2002. Prediction of ammonia emission from dairy barns using feed characteristics. Part II: Relation between urinary urea concentration and ammonia emission. J. Dairy Sci. 85:3389-3394.

Mosquera Losada, J. 2007. Measurement methods and strategies. Chapter 6 in Ammonia, the case of the Netherlands. D. A. J. Starmans and K. W. van der Hoek, ed. Wageningen Academic Publishers, Wageningen, the Netherlands.

Nousiainen, J., K. J. Shingfield, and P. Huhtanen. 2004. Evaluation of milk urea nitrogen as a diagnostic of protein feeding. J. Dairy Sci. $87: 386-398$.

Pankratz, A. 1991. Forecasting with Dynamic Regression Models. John Wiley \& Sons, New York, NY. 
Phillips, V. R., D. S. Lee, R. Scholtens, J. A. Garland, and R. W. Sneath. 2001. A review of methods for measuring emission rates of ammonia from livestock buildings and slurry or manure stores. Part 2: Monitoring flux rates, concentrations and airflow rates. J. Agric. Eng. Res. 78:1-14.

Pinder, R. W., N. J. Pekney, C. I. Davidson, and P. J. Adams. 2004. A process-based model of ammonia emissions from dairy cows: Improved temporal and spatial resolution. Atmos. Environ. $38: 1357-1365$

Powell, J. M., G. A. Broderick, and T. H. Misselbrook. 2008a. Seasonal diet affects ammonia emissions from tie-stall dairy barns. J. Dairy Sci. 91:857-869

Powell, J. M., T. H. Misselbrook, and M. D. Casler. 2008b. Season and bedding impacts on ammonia emissions from tie-stall dairy barns. J. Environ. Qual. 37:7-15.

Rajala-Schultz, P. J., and W. J. A. Saville. 2003. Sources of variation in milk urea nitrogen in Ohio dairy herds. J. Dairy Sci. 86:1653-1661.

Schepers, A. J., and R. G. M. Meijer. 1998. Evaluation of the utilization of dietary nitrogen by dairy cows based on urea concentration in milk. J. Dairy Sci. 81:579-584.

Schils, R. L. M., M. H. A. de Haan, J. G. A. Hemmer, A. van den Polvan Dasselaar, J. A. de Boer, A. G. Evers, G. Holshof, J. C. van Middelkoop, and R. L. G. Zom. 2007. DairyWise, a whole-farm dairy model. J. Dairy Sci. 90:5334-5346.

Scholtens, R., C. J. Dore, B. M. R. Jones, D. S. Lee, and V. R. Phillips. 2004. Measuring ammonia emission rates from livestock buildings and manure stores. Part 1: Development and validation of external tracer ratio, internal tracer ratio and passive flux sampling methods. Atmos. Environ. 38:3003-3015.

Schrade, S., K. Zeyer, L. Emmenegger, M. K. Vollmer, M. Keck, and E. Hartung. 2007. Ammonia emissions in naturally ventilated cattle housing with an exercise yard: Requirements and measuring concept using two tracer gases. Pages 345-346 in Ammonia Emissions in Agriculture. G. J. Monteny and E. Hartung, ed. International Conference on Ammonia in Agriculture, Ede, the Netherlands. Wageningen Academic Publishers, Wageningen, the Netherlands.

Smits, M. C. J., H. Valk, A. Elzing, and A. Keen. 1995. Effect of protein nutrition on ammonia emission form a cubicle house for dairy cattle. Livest. Prod. Sci. 44:147-156.
Smits, M. C. J., H. Valk, G. J. Monteny, and A. M. Van Vuuren. 1997. Effect of protein nutrition on ammonia emission from cow houses. Pages 101-107 in Gaseous Nitrogen Emissions from Grasslands. CAB International, Wallingford, UK.

Sommer, S. G., G. Q. Zhang, A. Bannink, D. Chadwick, T. Misselbrook, R. Harrison, N. J. Hutchings, H. Menzi, G. J. Monteny, J. Q. Ni, O. Oenema, and J. Webb. 2006. Algorithms determining ammonia emission from buildings housing cattle and pigs and from manure stores. Pages 264-335 in Advances in Agronomy. Vol. 89. D. L. Sparks, ed. Elsevier, London, UK.

Tamminga, S., W. M. van Straalen, A. P. J. Subnel, R. G. M. Meijer, A. Steg, C. J. G. Wever, and M. C. Blok. 1994. The Dutch protein evaluation system: The DVE/OEB system. Livest. Prod. Sci. 40:139-155.

Tas, B. M., H. Z. Taweel, H. J. Smit, A. Elgersma, J. Dijkstra, and S. Tamminga. 2006. Utilisation of $\mathrm{N}$ in perennial ryegrass cultivars by stall-fed lactating dairy cows. Livest. Sci. 100:159-168.

Tilley, J. M., and R. A. Terry. 1963. A two-stage technique for the in vitro digestion of forages crops. J. Br. Grassl. Soc. 18:104-111.

van der Stelt, B. P. C. J. van Vliet, J. W. Reijs, E. J. M. Temminghoff, and W. H. van Riemsdijk. 2008. Effects of dietary protein and energy levels on cow manure excretion and ammonia volatilization. J. Dairy Sci. 91:4811-4821.

van Duinkerken, G., G. André, M. C. J. Smits, G. J. Monteny, and L. B. J. Šebek. 2005. Effect of rumen-degradable protein balance and forage type on bulk milk urea concentration and emission of ammonia form dairy cow houses. J. Dairy Sci. 88:1099-1112.

van Es, A. J. H. 1975. Feed evaluation for dairy cows. Livest. Prod. Sci. 2:95-107.

van Es, A. J. H. 1978. Feed evaluation for ruminants. I. The systems in use from May 1978 onwards in the Netherlands. Livest. Prod. Sci. 5:331-345.

VROM. 2007. Letter KvI2007097080 of the Dutch Ministry of VROM (www.vrom.nl)

Wang, C., G. Zhang, H. B. Rom, J. S. Strøm, and B. Li. 2005. Comparing model estimation with measured ammonia emission data for naturally ventilated dairy cattle buildings with slatted floor. Pages 411-418 in Proc. Symp. Livestock Environment VII, Beijing, China. American Society of Agricultural and Biological Engineers, St. Joseph, MI. 